\title{
MOTIVASI PETERNAK TERHADAP KINERJA SISTEM BAGI HASIL USAHA TERNAK SAPI POTONG DI KECAMATAN MAIWA, KABUPATEN ENREKANG, PROPINSI SULAWESI SELATAN
}

\author{
Angga Nugraha, Musdalifa Mansyur, Dhian Ramadhanty
}

Corresponding author : anggasosek2010@gmail.com

Prodi Peternakan Universitas Muhammadiyah Sidenreng Rappang Jl. Angkatan 45 No. 1 A Telp. (0421) 93308 Lt. Salo-SidrapSul-Sel

\begin{abstract}
ABSTRAK : Kecamatan Maiwa tepatnya di Kabupaten Enrekang, merupakan salah satu daerah yang peternaknya mengembangkan usaha ternak sapi potong dengan penerapan sistem bagi hasil (teseng). Keberadaan Peternak melakukan sistem bagi hasil (teseng) di Kecamatan Maiwa dipandang positif sebagai salah satu cara untuk mencapai tujuan kesejahteraan bagi peternak yang melakukan sistem bagi hasil (teseng) namun menurut peternak, kesepakatan yang terbangun tidak dilakukan secara tertulis antara peternak dan pemilik modal, sehingga dalam pembagian hasilnya terkadang kurang menguntungkan bagi Peternak. Tujuan penelitian adalah untuk menganalisis motivasi peternak bagi hasil usaha ternak sapi potong dan faktorfaktor yang mempengaruhi motivasi peternak usaha ternak sapi potong dengan pola sistem bagi hasil. Waktu pengambilan data mulai bulan Januari - Februari 2017. Penelitian dilakukan di Kecamatan Maiwa Kabupaten Enrekang dan metode penelitian adalah survey. Sampel berjumlah 64 peternak diambil (total sampling). Metode analisis data yaitu pengujian model statistik menggunakan SEM Smart PLS (Partial Least Square) 2.0. Hasil penelitian menjelaskan bahwa 1. Motivasi peternak sistem bagi hasil usaha sapi potong yaitu memenuhi kebutuhan hidup keluarga, memenuhi kebutuhan sekolah anak-anak, memenuhi kebutuhan sekunder, hubungan dengan pemilik modal, hubungan dengan penyuluh, hubungan dengan pemerintah, hubungan dengan masyarakat, hubungan dengan peternak lain, memperoleh penghargaan dari sistem bagi hasil, serta memperoleh pengetahuan dan pengalaman beternak. 2. Faktor-faktor yang mempengaruhi motivasi peternak sistem bagi hasil usaha sapi potong yaitu jumlah ternak yang dimiliki, pendapatan non peternak, pendapatan sistem bagi hasil, penguasaan lahan pertanian, dan jumlah pedet yang dihasilkan.

Kata Kunci: motivasi peternak, kinerja, sistem bagi hasil, sapi potong skala kecil
\end{abstract}

\section{PENDAHULUAN}

\section{Latar Belakang}

Kecamatan Maiwa di Kabupaten Enrekang, Provinsi Sulawesi Selatan adalah salah satu daerah yang peternaknya mengembangkan usaha ternak sapi potong dengan penerapan sistem bagi hasil. Keberadaan Peternak melakukan sistem bagi hasil di Kecamatan Maiwa dipandang positif sebagai salah satu cara untuk mencapai tujuan kesejahteraan bagi peternak yang melakukan sistem bagi hasil. Peternak yang melakukan sistem bagi hasil di Kecamatan Maiwa, merupakan peternak yang sudah memiliki pengalaman dalam melakukan sistem bagi hasil yang berkisar antara 5-10 tahun secara turun- temurun.

Penerapan Sistem bagi hasil di Kecamatan Maiwa, melibatkan antara dua pihak yaitu antara pemberi modal dan peternak. Pihak yang memberikan modal merupakan pihak yang memiliki ternak sapi, akan tetapi tidak memiliki waktu yang cuku puntuk memelihara sapi tersebut sehingga pemilik modal memberikan sapi tersebut kepada peternak untuk dipelihara sesuai dengan perjanjian dan kesepakatan yang disepakati sebelumnya. Peternak menyatakan bahwa kesepakatan yang terbangun tidak dilakukan secara tertulis antara peternak dan pemilik modal, akan tetapi hanya mengedepankan konsep kepercayaan atau kekeluargaan sehingga dalam pembagian hasilnya terkadang kurang menguntungkan bagi Peternak.

Peternak akan termotivasi dalam bekerja 
apabila yang dilakukan itu dapat memenuhi kebutuhan hal ini sesuai dengan pendapat Wahjosumidjo (2001) menyatakan bahwa motivasi adalah kekuatan internal yang mendorong seseorang melakukan suatu tindakan. Sehubungan dengan itu. Hellriegel. et al,(1992) menambahkan bahwa ada tiga kelompok kebutuhan yang utama, yaitu yang pertama adalah pemenuhan keberadaan (Existence Needs), kedua hubungan dengan stake holder (Related Needs), dan yang ketiga memperoleh kemajuan (Growth needs). Penelitian memfokuskan pada ketiga faktor tersebut, dimana diperkirakan mempengaruhi motivasi peternak melakukan sistem bagi hasil.

\section{Tujuan Penelitian}

Penelitian bertujuan untuk

1. Mengetahui faktor-faktor apa yang mempengaruhi motivasi peternak melakukan sistem bagi hasil.

2. Menganalisis motivasi peternak yang melakukan sistem bagi hasil usaha ternak sapi potong di Kecamatan Maiwa, Kabupaten Enrekang.

\section{METODE PENELITIAN}

\section{Pengumpulan Data}

Penelitian dilaksanakan menggunakan metode survey. Penelitian dilaksanakan di Kabupaten Enrekang Khususnya di Kecamatan Maiwa pada bulan Januari - Februari 2017. Tempat lokasi penelitian Kecamatan Maiwa, Kabupaten Enrekang dengan penentuan lokasi Tabel 1. Pemenuhan Kebutuhan (Existence) dilakukan dengan secara sengaja (Purposive). Alasan memilih Kabupaten Enrekang sebagai lokasi penelitian karena Kabupaten Enrekang khususnya di Kecamatan Maiwa di Sulawesi Selatan merupakan sentra pengembangan peternakan sapi potong dengan pola usaha sistem bagi hasil. Sampel berjumlah 64 peternak diambil (total sampling) yaitu peternak yang telah melakukan sistem bagi hasil dengan lama beternak lebih dari 5 tahun.

\section{Analisa Data}

Analisis Motivasi Peternak Sapi Potong Terhadap Kinerja Sistem Bagi Hasil

\section{HASIL DAN PEMBAHASAN}

\section{Pemenuhan Kebutuhan (existence)}

Pemenuhan kebutuhan meliputi memenuhi kebutuhan hidup keluarga, memenuhi kebutuhan sekolah anak-anak, dan memenuhi kebutuhan sekunder.

Tabel 1 menunjukkan variabel pemenuhan kebutuhan yang diukur dengan menggunakan indikator memenuhi kebutuhan keluarga, kebutuhan sekolah anak-anak, dan kebutuhan sekunder didapatkan skala rata-rata 72,3 termasuk skala dengan kategori "Memenuhi". Berdasarkan Tabel 1dapat dilihat bahwa dari 3 pertanyaan yang berhubungan dengan pemenuhan kebutuhan pertanyaan 2 yaitu untuk memenuhi kebutuhan sekolah anak anak adalah pertanyaan memilki skala rata rata yang paling tinggi yaitu 86,5 , artinya pernyataan ini adalah pernyataan yang paling

\begin{tabular}{|c|c|c|c|c|c|c|c|c|c|c|c|}
\hline \multirow[t]{2}{*}{ Indikator } & \multicolumn{2}{|c|}{$\begin{array}{c}\text { Sangat } \\
\text { Tidak } \\
\text { Memenuhi }\end{array}$} & \multicolumn{2}{|c|}{$\begin{array}{c}\text { Tidak } \\
\text { Memenuhi }\end{array}$} & \multicolumn{2}{|c|}{ Netral } & \multicolumn{2}{|c|}{ Memenuhi } & \multicolumn{2}{|c|}{ Sangat Memenuhi } & \multirow[t]{2}{*}{$\begin{array}{c}\text { Skala Rata }- \\
\text { Rata(\%) }\end{array}$} \\
\hline & $\mathbf{F}$ & $\%$ & $\mathbf{F}$ & $\%$ & $\mathbf{F}$ & $\%$ & $\mathbf{F}$ & $\%$ & $\mathbf{F}$ & $\%$ & \\
\hline $\begin{array}{l}\text { Memenuhi kebutuhan } \\
\text { hidup keluarga }\end{array}$ & 1 & 1,6 & 42 & 65,6 & 17 & 26,6 & 2 & 3,1 & 2 & 3,1 & 48,1 \\
\hline $\begin{array}{l}\text { Memenuhi kebutuhan } \\
\text { sekolah anak-anak }\end{array}$ & - & - & - & - & 1 & 1,6 & 41 & 64,4 & 22 & 34,4 & 86,5 \\
\hline $\begin{array}{l}\text { Memenuhi kebutuhan } \\
\text { sekunder }\end{array}$ & - & - & 4 & 6,2 & 3 & 4,7 & 38 & 59,4 & 19 & 29,7 & 82,5 \\
\hline \multicolumn{11}{|c|}{ Skala rata - rata $\%$} & 72,3 \\
\hline
\end{tabular}

Sumber : Data Primer diolah, 2017 
Tabel 2. Hubungan dengan Stakeholder

\begin{tabular}{|c|c|c|c|c|c|c|c|c|c|c|c|}
\hline \multirow{2}{*}{ Indikator } & \multicolumn{2}{|c|}{$\begin{array}{c}\text { Sangat } \\
\text { Tidak Baik }\end{array}$} & \multicolumn{2}{|c|}{ Tidak Baik } & \multicolumn{2}{|c|}{ Netral } & \multicolumn{2}{|c|}{ Baik } & \multicolumn{2}{|c|}{$\begin{array}{c}\text { Sangat } \\
\text { Baik }\end{array}$} & \multirow{2}{*}{$\begin{array}{l}\text { Skala Rata - } \\
\quad \text { rata(\%) }\end{array}$} \\
\hline & $\mathbf{F}$ & $\%$ & $\mathbf{F}$ & $\%$ & $\mathbf{F}$ & $\%$ & $\mathbf{F}$ & $\%$ & $\mathbf{F}$ & $\%$ & \\
\hline $\begin{array}{l}\text { Hubungan dengan } \\
\text { pemilik modal }\end{array}$ & - & - & 3 & 4.7 & 5 & 7.8 & 46 & 71.9 & 10 & 15.6 & 79,6 \\
\hline $\begin{array}{l}\text { Hubungan dengan } \\
\text { penyuluh }\end{array}$ & - & - & - & - & 1 & 1.6 & 54 & 84.4 & 9 & 14.1 & 82,5 \\
\hline $\begin{array}{l}\text { Hubungan dengan } \\
\text { pemerintah }\end{array}$ & - & - & - & - & 2 & 3.1 & 31 & 48.8 & 31 & 48.8 & 89 \\
\hline $\begin{array}{l}\text { Hubungan dengan } \\
\text { masyarakat }\end{array}$ & - & - & - & - & - & - & 40 & 62.5 & 24 & 37.5 & 77,7 \\
\hline $\begin{array}{l}\text { Hubungan dengan } \\
\text { peternak lain }\end{array}$ & - & - & - & - & 2 & 3.1 & 35 & 54.7 & 27 & 42.2 & 87,8 \\
\hline \multicolumn{11}{|c|}{ Skala rata - rata \% } & 83,3 \\
\hline
\end{tabular}

Sumber : Data Primer diolah, 2017

banyak disetujui oleh peternak untuk dijadikan alasan melakukan usaha ternak sapi potong. Hal ini sesuai dengan penelitian Hartono (2011) yang menjelaskan bahwa usaha memelihara ternak sapi potong bagi petani merupakan salah satu bagian untuk mendukung dalam memenuhi kebutuhan

Tabel 2 menunjukkan variabel hubungan dengan stake holder yang diukur dengan menggunakan indikator hubungan dengan pemilik modal, hubungan dengan penyuluh, hubungan dengan pemerintah, hubungan dengan masyarakat sekitar, dan hubungan dengan peternak lain didapatkan skala rata-rata 83,3 termasuk skala dengan kategori "Sangat baik" . Berdasarkan Tabel dapat di lihat bahwa dari 5 pertanyaan yang berhubungan dengan hubungan dengan stake holder pertanyaan 3 yaitu hubungan dengan pemerintah adalah pertanyaan yang memilki skala rata-rata yaitu yang paling tinggi yaitu 89 artinya pernyataan ini adalah pertanyaan yang paling banyak disetujui oleh peternak untuk dijadikan alasan melakukan usaha ternak sapi potong.

Tabel 3. Memperoleh Kemajuan peternak.

\section{Hubungan dengan Stakeholder}

Hubungan dengan stake holder meliputi hubungan dengan pemilik modal, hubungan dengan penyuluh, hubungan dengan pemerintah, hubungan dengan masyarakat, dan hubungan dengan peternak lain.

Dukungan pemerintah terhadap usaha peternakan sapi potong yang mempunyai andil besar dalam pemenuhan protein hewani masyarakat dan usaha peternakan dipandang sebagai usaha potensial bagi peningkatan pendapatan masyarakat. Dukungan pemerintah ini diwujudkan dalam bentuk deregulasi peternakan (Mustofa, 2015).

\section{Memperoleh Kemajuan}

Kebutuhan untuk memperoleh kemajuan meliputi memperoleh penghargaan dari sistem bagi hasil, memperoleh pengetahuan dan pengalaman beternak.

Pada hasil penelitian yang ditunjukkan Tabel 3, variabel memperoleh kemajuan yang diukur dengan menggunakan indikator memperoleh penghargaan, dan memperoleh

\begin{tabular}{|c|c|c|c|c|c|c|c|c|c|c|c|}
\hline \multirow[t]{2}{*}{ Indikator } & \multicolumn{2}{|c|}{$\begin{array}{c}\text { Sangat } \\
\text { Tidak } \\
\text { Memenuhi }\end{array}$} & \multicolumn{2}{|c|}{$\begin{array}{c}\text { Tidak } \\
\text { Memenuhi }\end{array}$} & \multicolumn{2}{|c|}{ Netral } & \multicolumn{2}{|c|}{ Memenuhi } & \multicolumn{2}{|c|}{$\begin{array}{c}\text { Sangat } \\
\text { Memenuhi }\end{array}$} & \multirow[t]{2}{*}{$\begin{array}{c}\text { Skala Rata - } \\
\text { rata(\%) }\end{array}$} \\
\hline & $\mathbf{F}$ & $\%$ & $\mathbf{F}$ & $\%$ & $\mathbf{F}$ & $\%$ & $\mathbf{F}$ & $\%$ & $\mathbf{F}$ & $\%$ & \\
\hline $\begin{array}{l}\text { Memperoleh penghargaan } \\
\text { dari sistem bagi hasil }\end{array}$ & - & - & 5 & 7,8 & 1 & 1,6 & 38 & 59,4 & 20 & 31,2 & 82,8 \\
\hline $\begin{array}{l}\text { Memperoleh pengetahuan } \\
\text { dan pengalaman beternak }\end{array}$ & - & - & 3 & 4,7 & 2 & 3.1 & 39 & 60,9 & 20 & 31,2 & 83,7 \\
\hline \multicolumn{11}{|c|}{ Skala rata - rata \% } & 83,2 \\
\hline
\end{tabular}

Sumber : Data Primer diolah, 2017 
pengetahuan dan pengalaman beternak didapatkan skala rata-rata termasuk skala dengan kategori "Memenuhi". Berdasarkan Tabel 3 dapat dilihat bahwa dari 2 pertanyaan yang berhubungan dengan kebutuhan keberadaan pertanyaan 2 yaitu memperoleh pengetahuan dan pengalaman beternak adalahpertanyaan yang memiliki skala ratarata yang adalah pertanyaan yang paling banyak di setujui oleh peternak untuk maka motivasi untuk beternak juga semakin rendah.

\section{KESIMPULAN}

1. Motivasi peternak sistem bagi hasil usaha sapi potong di Kecamatan Maiwa Kabupaten Enrekang yaitu memenuhi kebutuhan hidup keluarga, memenuhi kebutuhan sekolah anak-anak, memenuhi kebutuhan sekunder, hubungan dengan pemilik modal, hubungan dengan penyuluh, hubungan dengan pemerintah, hubungan dengan masyarakat, hubungan dengan peternak lain, memperoleh penghargaan dari sistem bagi hasil, sertamemperoleh pengetahuan dan pengalaman beternak.

2. Faktor-faktor yang mempengaruhi motivasi peternak sistem bagi hasil usaha sapi potong di Kecamatan Maiwa Kabupaten Enrekang yaitu jumlah ternak yang dimiliki, pendapatan non peternak, pendapatan sistem bagi hasil, penguasaan lahan pertanian, dan jumlah pedet yang dihasilkan.

\section{Saran}

Saran yang dapat diberikan untuk penelitian-penelitian selanjutnya yaitu mengeksplor variabel-variabel lain yang belum diteliti sebelumnya. Sedangkan saran yang diberikan untuk peternak yaitu membuat dijadikan alasan paling tinggi yaitu 83,2, artinya pernyataan ini melakukan usaha ternak sapi potong.

Tingginya motivasi peternak juga disebabkan karena tingginya pengalaman responden dalam peternakan sapi. Luamase (2011) menyatakan semakin tinggi pengalaman peternak, maka motivasi untuk beternak semakin tinggi pula, sebaliknya semakin rendah tingkat pengalaman peternak, peraturan yang tertulis antara peternak dan pemilik modal.

\section{DAFTAR PUSTAKA}

Hartono. B. Analisis Ekonomi Rumahtangga Peternak Sapi Potong di Kec.Damsol Kabupaten Donggala, Provinsi Sulawesi Tengah. Jurnal Ternak Tropika, 12(1):6067

Hellriegel D, Slocum J W, and Richard W. 1992. Organization Behavior. New York. Penerbit:West Publishing Company

Luanmase C M, Nurtini S, Haryadi F T. 2011. Analisis Motivasi beternak sapi potong bagi peternak lokal dan transmigran serta pengaruhnya terhadap pendapatan di Kecamatan Kaipau, Kabupaten Seram Bagian Barat. Buletin Peternakan 35(2):113-123

Mustafa, A. N. Wahyuning D, Muhammad A. 2015. Analisis Faktor yang mempengaruhi pengembalian keputusan peternak dalam memakai ternak sapi potong di Desa Kedongkumpul Kecamatan Sari Rejo Kabupaten Lamongan. Universitas Islam Lamongan Fakultas Peternakan. Jurnal Ternak 06(1): 26-30

Wahyjosumidjo. 2001. Kepemimpinan dan Motivasi. Penerbit Ghalia Indosnesia, Cetakan 3. Jakarta Timur. 